Ecosystem services of the Arctic NWR

1

4

5

6

7

8

9

10

11

12

13

14

15

16

17

18

19

20

21

22

23

24

25

26

27

18

\section{Comprehensive valuation of the ecosystem services of the Arctic National Wildlife Refuge}

(

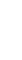

10

(1)

(1)

\author{
Adam C. Turner ${ }^{1,2}$, Margaret A. Young ${ }^{1,3}$, Maureen R. McClung ${ }^{1}$, Matthew D. Moran ${ }^{1,4}$
}

13

4

\author{
${ }^{1}$ Biology Department, Hendrix College \\ 1600 Washington Ave, Conway, AR, 72032
}

6

7

92 Current address: Texas A\&M Forest Service, 414 NW 25th Street, Mineral Wells, TX 76067

${ }^{3}$ Current address: Arkansas Public Policy Panel, 1308 W 2nd St., Little Rock, AR 72201

$1 \quad{ }^{4}$ Corresponding author, moran@ @endrix.edu, 501-450-3814

2

\title{
Acknowledgements
}

4 Thanks to the staff of the Arctic National Wildlife Refuge for their help in data collection. L.

25 Kennedy assisted with development of the contingency valuation survey. T. Fullman, N.

66 Whittington-Evans, and D. Krause read early drafts of this manuscript and provided insightful

27 feedback. 
Ecosystem services of the Arctic NWR

\section{Abstract}

Ecosystem services (ES) have been well studied in most biomes, but the Arctic tundra has received little attention, despite covering over $10 \%$ of terrestrial Earth. Using established ES methodologies, we calculated values for the United States Arctic National Wildlife Refuge, a region virtually undisturbed by humans, but slated for future oil and gas drilling. We estimated the Refuge is worth about 1,709 USD/hectare/year, equal to over 13 billion USD annually. Globally important services, such as climate regulation (e.g., carbon storage) and non-use services (e.g., aesthetic information), contributed the most value and were similar to valuations from more productive ecosystems. Local services made smaller contributions to the total, but they remain vitally important to local indigenous cultures. Strikingly, a contingent valuation survey of U.S. residents found that, after neutral educational information, willingness-to-pay to maintain the Refuge in its current state exceeded estimated values of the oil and gas deposits. Our study shows that citizens may value Arctic habitats beyond their traditional economic development potential. Our comprehensive ecosystem services valuation suggests that maintaining the Refuge in its current condition (i.e., de facto wilderness) with its full range of ES is more valuable to humanity compared to development for oil and gas.

Keywords: Arctic National Wildlife Refuge, arctic tundra, climate regulation, contingent valuation, ecosystem services, oil and gas drilling 
Ecosystem services of the Arctic NWR

\section{Declarations}

49 Funding: This study was supported by the Hendrix College Odyssey Program

50 Conflicts of Interest/Competing Interests: The authors report no conflicts of interest.

51 Ethics Approval: The survey included in this paper was reviewed and approved by the Hendrix

52 College Human Subjects Review Board.

53 Consent to Participate: N.A. All survey participants provided consent.

54 Consent for Publication: All authors reviewed the manuscript and approve of its publication.

55 Availability of Data: All data can be obtained by contacting the corresponding author.

56 Code Availability: N.A.

57 Authors' Contribution: ACT, MAY, MRM, and MDM designed the study, collected and

58 analyzed data, and wrote the drafts of the paper. MRM and MDM edited the final document. 
Ecosystem services of the Arctic NWR

\section{Introduction}

Ecosystem services (ES) assessments place an economic value on resources in natural landscapes that are beneficial to humans. In recent decades, most biomes have had multiple ES values estimated (Costanza et al. 1997; Costanza et al. 2014; de Groot et al. 2012) with global annual ecosystem services values calculated at over $\$ 100$ trillion dollars a year (de Groot et al. 2012; Costanza et al. 2014). However, two biomes that cover a large proportion of the terrestrial surface remain relatively understudied: desert and tundra (Malinauskaite et al. 2019). Taylor et al. (2017) developed a valuation for a portion of the Chihuahuan Desert and O'Garra (2017) has provided an estimate of some key ecosystem services for Arctic tundra. Considering that Arctic tundra alone covers 5.7 million $\mathrm{km}^{2}$ (Shaver et al. 1992) of the earth's surface and, by one estimate, contains 50\% of the global belowground organic carbon (Tarnocai et al. 2009), it is likely that this biome contributes a large amount of ecosystem services (O’Garra 2017).

Arctic tundra is composed of relatively low productivity ecosystems, but these may still provide numerous ecosystem services on both a local and global scale. Tundra contains large stores of carbon, mostly located in the permafrost layer (Tarnocai et al. 2009), and is therefore vitally important for global climate regulation (Zimov et al. 2006). Productive fisheries occur in Arctic coastal territories (CAFF 2015), providing food both locally and for export (Zeller et al. 2011; Christiansen et al. 2014). Arctic tundra is largely undeveloped compared to other biomes (Watson et al. 2016), has significant wildlife populations (Johnson et al. 2005), and supports unique cultures (Hovelsrud et al. 2011), further increasing its likely contribution to a variety of information functions (e.g., recreational, aesthetic, cultural, scientific understanding, de Groot et
al. 2002). 
Ecosystem services of the Arctic NWR continents. As global temperature rises, the polar regions are increasing in temperature more rapidly than equatorial zones (Hansen et al. 2006, 2010), causing rapid environmental and social changes to these high latitudes (Wookey et al. 2009; Bhatt et al. 2013; Chapin et al. 2015). Furthermore, oil and natural gas extraction is expanding into new areas of the Arctic, causing

87 increased fragmentation, decline of ecosystem function, and negative impacts on wildlife (Boulanger et al. 2012; Johnson and Russell 2014) in areas that were previously some of the most intact ecosystems on Earth (Sanderson et al. 2002; Watson et al. 2016). As the globe continues to warm, Arctic areas are becoming more accessible to industrial development, especially by petroleum industries (Harsem et al. 2011). Considering that the circumpolar region

92 is estimated to contain large quantities of oil and gas, up to $22 \%$ of the global reserves (Bird et al. 2008), enhanced fossil fuel extraction could further exacerbate climate change. Currently,

94 there is little information on how ES relate to management of specific Arctic regions

95 (Malinauskaite et al. 2019)

In the United States, Arctic tundra covers around one-third of the state of Alaska and

97 plays an important role in the state's economy. About 17\% of the Alaskan tundra region is protected by the Arctic National Wildlife Refuge (Ibisch et al. 2016), which is one of the largest

99 contiguous natural areas in the U.S. There is no road access to the Refuge, resulting in low human visitation. As such, the remoteness of the area provides a prime opportunity to study an undisturbed tundra landscape. The Refuge is also important to the subsistence, culture, and spiritual life of native people who live in and around the region. However, this area is under increasing threat from energy industries. Large oil and natural gas reserves are thought to occur

104 in the Refuge (estimated at more than 10 billion barrels of oil; Attanasi 2005), mostly in the 
Ecosystem services of the Arctic NWR

105

106

107

108

109

110

111

112

113

114

115

116

117

118

coastal plain region (known as the 1002 Area). When the Refuge was created in 1980, the U.S. Congress directed that additional natural and cultural resource studies occur in the 1002 area so that a future Congress could be better informed about potential oil and gas development. An intense public debate ensued with numerous unsuccessful attempts to open the area for drilling. More recently, the Tax Cuts and Jobs Act of 2017 (H.R.1 2018) was passed by the U.S. Congress and signed by the President, allowing for oil and natural gas exploration to proceed. By early 2020, no activity has yet commenced while environmental impact assessments are conducted. Our primary goal in this study was to determine the ES values for the Arctic National Wildlife Refuge. Assuming the Arctic National Wildlife Refuge is representative of typical Arctic tundra habitat, this value can be added to the global ES estimate. This estimation could also be utilized to understand the impact of planned energy development. Since no ES estimates have been calculated for the Arctic National Wildlife Refuge, the true costs and benefits of planned oil exploration and production cannot be accurately determined. This ES value should be calculated prior to resource extraction so that we can determine if the ES value of the Arctic National Wildlife Refuge is greater or less than the economic benefits of fossil fuel development.

\section{Methods}

Study Site

The Arctic National Wildlife Refuge is located in the northeastern corner of Alaska and covers about 78,000 $\mathrm{km}^{2}$ (Fig. 1). It was established as a protected area in 1960 and expanded in 1980 under the Alaska National Interest Lands Conservation Act (Public Law 97-394 1980).

That law designated the 1.2 million acres of the coastal plain section (1002 Area) for potential oil and gas development, but only with future U.S. Congressional approval. 
Ecosystem services of the Arctic NWR

The Arctic National Wildlife Refuge is noted for its high Arctic biodiversity, roadless and wilderness characteristics, and large populations of animals (United States Bureau of Land Management 1986). It is particularly important for the Porcupine Caribou Herd (Rangifer tarandus granti), which calves annually on the coastal plain (Whitten et al. 1992), denning polar

132 bears, and the large number of migratory birds which utilize the region for breeding (Douglas et al. 2002; Brown et al. 2007). Much of the Refuge is covered in typical Arctic tundra habitat, with smaller areas of boreal forest in the southern portions. It is considered by many scientists as one of the finest remaining Arctic habitats in the world (Brown 2002; National Research Council 2003).

Very few people live in the vicinity of the Refuge. The village of Kaktovik (population:

138 241) is located within the Refuge boundary along the Arctic coast and Arctic Village

139 (population: 152) is located on the southern boundary of the Refuge (Fig. 1). Additionally, 140 villages to the east in Canada, south along the Yukon River watershed, and southwest of the 141 Refuge also utilize refuge resources. While these Alaska Native villages do not contain large 142 population numbers, they depend very heavily on the subsistence and cultural resources of the 143 Refuge.

$144 \quad$ Estimating Ecosystem Services

145 We utilized the TEEB (2010) classification system, originally described in de Groot et al.

146 (2002) as the model for classifying ecosystem services provided by biological systems (Fig. 2).

147 While there are several different ES classification systems commonly utilized, there are broad 148 similarities between each, making them roughly comparable (Costanza et al. 2017). We 149 estimated each category of ES values using methods described in the literature (Costanza and 150 Folke 1997; de Groot et al. 2012; Costanza et al. 2014, and described in detail below). We 
Ecosystem services of the Arctic NWR

151 performed a comprehensive analysis of all the services established by de Groot et al. (2002) and

152 TEEB (2010), recognizing that not all services are likely to be prominent in an Arctic

153 environment. Since we had no a priori knowledge about which individual services were present,

154 we attempted to calculate and report on all ES values regardless of their amount or explained

155 why they were not found in this environment. All monetary estimates were inflation-adjusted to

1562016 USD.

157 Food

Small numbers of Alaska Native people live in and around the Arctic National Wildlife

Refuge and obtain food from the local environment, a practice that has occurred for thousands of

years. We therefore estimated the value of food gathered by native people from the Arctic

161 National Wildlife Refuge that replaces commercially-purchased food. We began by calculating

162 the population of native people in the Arctic National Wildlife Refuge region. We created a

163 buffer that extended $80 \mathrm{~km}$ from the border of the Refuge and identified all of the towns inside

164 this border. We downloaded data for 2016 city population sizes from the U.S. Census Bureau

165 (U.S. Census Bureau 2010). We totaled the entire population of the 80-km radius and then multiplied it by the percentage of individuals in the region that identified as American Indian or

167 Alaska Native on the U.S. National 2010 Census (U.S. Census Bureau 2010). Some wildlife

168 travels well beyond this $80-\mathrm{km}$ buffer, but we included those calculations under Nursery

169 Services. It is important to note that most of the population we identified lives either within the

170 refuge (Kaktovik) or on the boundary of the refuge (Arctic Village). These populations are

171 highly dependent on resources from within the protected area (USFWS 2010). The most

172 important animal resource (porcupine caribou herd) is seasonally dependent upon Refuge lands

173 where they calve each year (Whitten et al. 1992). So, while hunting and gathering occurs both 
Ecosystem services of the Arctic NWR

174 within and outside of the Refuge boundaries, the protected area is vitally important to

175 maintaining ecosystem function throughout the broader geographic area.

To estimate the proportion of daily caloric intake provided by hunting and gathering, we

177 utilized the list of wild food types consumed by the native Gwich'in people (e.g., caribou,

178 waterfowl, rabbit, and berries) as a representative of local Native Alaska populations, and then

179 identified the number of calories per 100 grams of each food source (Center for Indigenous

180 People's Nutrition and Environment 2008). We found the average amount (grams) consumed per

181 day for the foods we identified (Schuster et al. 2011). We then divided the total number of

182 calories consumed in traditional foods by 2000 , an estimate of the average daily caloric intake in

the U.S. (U.S. Department of Agriculture 2016).

We estimated the cost per year of food using data from a 2016 survey completed by the utilized the midpoint value of the cost per week per family of four and standardized this value on a per person per year basis. We then multiplied this value by the number of people in our study region who identified as Native Alaskan or American Indian in the 2010 census (U.S. Census Bureau 2010) to estimate the total cost of food for our entire population per year. We multiplied this value by the proportion of daily caloric intake provided by traditional means and divided by 191 the number of hectares in the entire refuge. Because of the remoteness of the area, food costs on 192 the North Slope of Alaska are likely higher than the state average, which would make our 193 estimate conservative. However, our method of food value calculation does not take into account 194 costs of obtaining food through hunting and gathering, including labor, materials, and equipment, 195 costs that are difficult to calculate. More complex valuations would account for actual costs of imported food as well as costs of acquiring food locally. 
Ecosystem services of the Arctic NWR

We should also note that in ES valuations, estimates for climate regulation often include some measure of food production, since alteration of carbon storage capacity would presumably have an impact on that food production value (see Climate Regulation). Thus, using the methods of O'Garra (2017), we assumed that climate change caused by release of stored carbon would reduce food production value by $50 \%$. Since it was adjusted by one-half, this approach prevented

202 double counting the current food production value,

Water

To estimate the value of water in Arctic National Wildlife Refuge, we first found the average household water costs in the state of Alaska. The Alaska Department of Environmental Conservation Division of Water reported that rural Alaskans often spend more than 5\% of their monthly household income on water systems (ADEC 2016). To estimate the number of households, we multiplied the labor force participation rate for 2016 (Tiberi 2017) by the total

209 estimated population in the two communities adjacent to the Arctic National Wildlife Refuge

210 that obtain water directly from the ecosystems within or dependent on the Refuge (Stankiewicz

211 2005; ADEC 2016; Fig. 1). We multiplied annual household income by 5\% to find the total 212 dollar value of water utilized from the Refuge. This number was divided by the total hectares of

213 the Refuge to find the value per hectare. It should be noted that by selecting the value of 5\%, our

214 estimate is conservative (ADEC 2016), but our analysis also does not account for labor and 215 materials.

Raw Materials 
Ecosystem services of the Arctic NWR

materials are presumably collected in the Refuge by members of the local indigenous communities, but data on exact quantity of materials collected are not currently available.

\section{Genetic Resources}

223 found species counts for plant and vertebrate species (USFWS 2011, 2017a, 2017b). Due to the

224 high diversity of arthropods and lack of knowledge on arthropod diversity, we used a well-

225 known order, Lepidoptera, to determine the size of all arthropod diversity. We identified the

226 number of species in Lepidoptera, and then extrapolated the total arthropod diversity using a

227 proportional representative comparison (Zhang 2011). Other biodiverse taxa, such as Nematoda

228 and Bacteria, were excluded due to a lack of information on species richness. Therefore, our total

229 estimate is conservative. To identify the potential economic value, we used the midpoint value of

230 bio-prospecting determined by Nunes and van der Bergh (2001), where they calculated a range

231 of monetary values for species. We then multiplied this number by the estimated number of

232 species and divided by the number of hectares.

This method is limited by both the high uncertainty in species diversity (especially small

234 organisms, such as prokaryotes) and value of those existing species. Individual species can be

235 extremely valuable to humanity directly (high market value, e.g., thermophilic bacteria in

236 Yellowstone NP; Hunter-Cervera 1998) or indirectly through keystone ecological functions (e.g.,

237 sea otters in the eastern Pacific; Estes and Palmisano 1974). It is unknown if any individual

238 species of the Refuge fit either of those categories. 
Ecosystem services of the Arctic NWR

Medicinal resources were calculated as part of the total economic value in bio-

241 prospecting based on Nunes and van der Burgh (2001). We assumed medicinal values were

242 incorporated into the calculated value for Genetic Resources.

Ornamental Resources

To calculate a value for ornamental resources, we searched for local products that were

245 collected and sold for ornamental uses. Regulations within the Refuge restrict plant collection,

246 except for subsistence purposes, and there are no data readily available to calculate the number

247 of ornamental plants collected in the area. We also contacted Alaska state government officials

248 to ask about studies on ornamental business performed by their commerce department, and we

249 were informed that there have been no studies done on the subject. Therefore, while we suspect

250 that there are some biological resources harvested for ornamental reasons, we have no data to

251 estimate the value.

252 Air Quality Regulation

253 It is well known that terrestrial plant cover removes air pollutants, which presumably has

254 a causative effect on lowering health care costs (Brunekreef and Holgate 2002). The Arctic

255 region, although relatively low in pollution sources, does have air pollution impacts from both

256 local and remote locations (Law and Stohl 2007). Nowak et al. (2014) estimated the county level

257 effect of tree cover on health care costs for the conterminous U.S. To estimate the value of

258 vegetation in air quality regulation for the Refuge, we selected the midpoint value of the lower

259 range of vegetational cover estimated by Nowak et al. (2014) and multiplied this number by the

260 number of hectares in the Refuge. We used this midpoint value from the lower range because the

261 Refuge is virtually treeless (except in the far southern areas), the value represents areas of the 
Ecosystem services of the Arctic NWR

262

263

264

265

266

267

268

269

270

271

272

273

274

275

276

277

278

279

280

281

282

283

284

U.S. that are similar in vegetation (i.e., treeless areas of the Great Plains), and plant removal of pollutants are, therefore, likely in the lower range.

\section{Climate Regulation}

Climate regulation by $\mathrm{CO}_{2}$ and $\mathrm{CH}_{4}$, unlike many other local regulation services, has

effects on a global scale through effects on temperature, short- and long-term weather patterns, and myriad geochemical processes. Therefore, both the stored carbon and the annually sequestered carbon have an impact on global climate and are, therefore, ecosystem services that the lands of the Arctic National Wildlife Refuge provide to the globe. Using geospatial data from the Alaska Land Carbon Assessment (Genet et al. 2017), we assessed three carbon metrics for the following categories: stored soil carbon, live carbon biomass, and carbon sequestration. This approach allowed us to determine the amount of carbon stored and the avoidance cost if we were to remove the Refuge's carbon storage capacity. For each carbon category, the number of pixels for each class within the Refuge boundary was calculated in ArcMap using the Zonal Statistics tool and these numbers were multiplied by the corresponding class value. The total values for each class were then summed to determine the total amount of carbon in the Refuge and then converted to a per hectare basis. Since loss of living plants and stored soil carbon would be a one-time event, these two values were prorated over 25 years. Release of stored carbon from permafrost is expected to consist both $\mathrm{CO}_{2}$ and $\mathrm{CH}_{4}$, although the ratios are uncertain. We used a value of $2 \%$ methane and the balance $\mathrm{CO}_{2}$, which we consider a conservative estimate of what proportion of the carbon would be released in this form (Schuur et al. 2015). Methane was considered to have 21 times the global climate change impact (in terms of heat trapping ability) compared to $\mathrm{CO}_{2}$ (IPCC 2007). This total value of carbon was based on the estimated social cost of climate change associated with increased atmospheric carbon (Tol 2008). Our valuation 
Ecosystem services of the Arctic NWR

285 therefore, calculates the total global social costs if all the carbon currently stored and sequestered

286 in the Refuge was instead present in the atmosphere.

287 Moderation of Disturbance

288 Most of the human population that could be affected by flood waters from the Arctic

289 National Wildlife Refuge live in the Yukon River Basin downstream from the Refuge. To

290 calculate a value for the water control provided by the Refuge, we began by overlaying the GIS

291 layer for the Yukon River basin over a map of the Arctic National Wildlife Refuge. This map

292 allowed us to calculate the proportion of Yukon River that overlaps the Refuge. We then

293 determined the value of insured properties along the Yukon River and its tributaries (FEMA

294 2016). We included the tributaries because the major source of flooding on the Yukon is ice jams

295 that back up the river through its tributaries and cause it to flood (Brabets et al. 2000). Based on

296 recent flood frequencies, we assumed a current annual flood risk of 4\% (Livingston et al. 2009)

297 and that each flood caused a $50 \%$ loss of property. From the total amount of insured property

298 value, we took the percentage of the river basin that falls in the Refuge and multiplied it by the

299 total insurance liability to find the value of water control. We assumed that if the Refuge did not

300 exist as its current water control landscape, there would be a $10 \%$ increase in flood frequency

301 and a 25\% increase in intensity (Konrad 2003; Taylor et al. 2017). We divided this total

302 estimated increase in monetary flood damage by the number of hectares in the Refuge to give us

303 the value per hectare per year. It should be noted that there are numerous uninsured properties in

304 the watershed (e.g., fishing and hunting cabins), so our estimates are likely conservative. 
Ecosystem services of the Arctic NWR

Flood damage and ground water recharge were included in Moderation of Disturbance

and Water categories, respectively. We did not identify any other water flow regulation services

outside of these two groups.

\section{Waste Treatment}

Wastewater treatment costs were included in calculations in Water.

Erosion Prevention

We considered erosion prevention as part of Soil Fertility Maintenance and Moderation

313 of Disturbance and, to avoid double counting, assumed the ES value for erosion prevention is

314 included within those two calculations.

\section{Soil Fertility Maintenance}

Soil fertility contributes to provisioning service values, so to avoid double counting and

317 to focus on end products (Pascual et al. 2010), we did not calculate monetary values for this

318 service. We did, however, examine three soil nutrients (nitrogen, phosphorous, potassium) that

319 have environmental and economic value so that we could estimate how much of these materials

320 is stored in this Arctic system. The storage of these material likely has economic benefits beyond

321 provisioning services, but for which we had no practical way to value. For instance, the

322 sequestered nitrogen and phosphorus reduces human-induced overabundance of these

323 compounds in the environment.

Nitrogen $(\mathrm{N})$ was estimated by considering two metrics: annual nitrogen deposition and

325 stored soil nitrogen. For deposition, we used a dataset retrieved from EarthDATA with global

326 terrestrial coverage indicating the amount of atmospheric nitrogen deposition in $\mathrm{mg} / \mathrm{m}^{2} / \mathrm{yr}$

327 (Dentener 2006). The number of pixels for each category within the Refuge boundary was 
Ecosystem services of the Arctic NWR

corresponding class value for nitrogen deposition. The total values for each class were then summed to determine the total amount of nitrogen deposition in the Refuge and then converted to a per hectare basis. Stored nitrogen values were obtained from a spatial data set produced by Shangguan et al. (2014). The number of pixels for each category was calculated as above and summed to determine the total amount of nitrogen stored in the Refuge.

Soil phosphorus (P) amounts were determined by estimates of average soil concentrations from the world's biomes (Xu et al. 2013). Similarly, for potassium (K), we obtained the average soil concentrations of this nutrient in soils found in the tundra biome (Sardans and Peñuelas 2015).

\section{Pollination}

There are no crops in the region to be pollinated. We assumed the value of gathered foods that require pollination is included in Food.

\section{Biological Control}

We assumed the ES values for natural biological control services provided by the ecosystem were included in Food production.

\section{Nursery Services}

To calculate our value for nursery services we identified the number of waterfowl harvested in both Canada and the United States. Using distribution maps from Bird Life International's database (BirdLife International 2018), we identified the hunted waterfowl whose breeding ranges overlapped with the Arctic National Wildlife Refuge. We then calculated the overlap of these breeding ranges with the refuge to calculate the percentage of the breeding ranges that occur in the Refuge. We applied these proportions to the number of harvested birds of each species in U.S. and Canada to identify the number of birds harvested that were likely 
Ecosystem services of the Arctic NWR

352 produced (i.e., fledged) from the refuge. We identified the average amount spent per bird by

353 using a national survey (Raftovich et al. 2017). To identify the total expenditure, we multiplied

354 the average annual expenditure by the number of hunters. We divided this number by the

355 proportion of days spent hunting migratory birds then divided this value by the number of

356 waterfowl harvested in 2016-17 to get the average expenditure per bird harvested. This number

357 was then multiplied by the number of harvested birds that were produced in the Refuge and

358 harvested in the U.S. and Canada. We divided this by the number of hectares to develop the price

359 per hectare. This value does not include subsistence waterfowl harvesting, which was included in

360 Food.

Other species were not included in nursery services. Small numbers of fish (salmon) are

362 produced in the Refuge and migrate elsewhere, but these data were unavailable. Caribou, which

363 do calve in the Refuge, were included in our Food calculation. Polar bears, which have

364 important, but difficult to calculate ecological and cultural values, den in the coastal plain of the

365 Refuge, but we attempted no valuation for this species.

Genepool Protection

We assumed value of genepool protection was calculated within sections for Genetic

Resources and Medicinal Resources.

\section{Total Non-use Value}

To calculate the value of total non-use value, we created a nationwide survey utilizing

371 contingent valuation methods (See Appendix). This survey was created using Google Forms and

372 distributed through Amazon's Mechanical Turk service to 315 participants. Survey respondents

373 were required to be U.S. citizens and above the age of 18 years old. 
Ecosystem services of the Arctic NWR

375 Wildlife Refuge. Those not familiar were re-directed to an unbiased educational section outlining

376 the location, size, biodiversity, and oil/gas resources of the area. Those that were familiar with

377 the Refuge were then asked if they supported oil and gas drilling in Arctic National Wildlife

378 Refuge. Then participants were asked how much of their annual income they would be willing to

379 forgo to ensure that the Refuge stayed closed to oil and gas drilling operations and for it to

380 remain in its natural state. They were then directed to the same supplemental education material

381 that those unfamiliar with the Refuge were shown. After the passage, we asked if the participants

382 supported oil and gas drilling in the Refuge and how much of their annual income, if any, they

383 would be willing to forgo to ensure that the Refuge remained closed to oil and gas drilling. We

384 did not attempt to differentiate why survey participants valued the Refuge in its natural state, but 385 assumed that those reasons encompassed all non-use values (e.g., aesthetic, spiritual, art, culture, 386 among others, both current and future).

The value utilized in our final calculations was the initial value of those familiar with the

Refuge. The average willingness to forgo income was applied to the percentage of those familiar with the Refuge. The percentage of participants familiar with the Refuge was applied to the

391 Refuge would have a \$0 willingness to forgo income. We then extrapolated the average U.S.

392 citizen's willingness to forgo income to the entire U.S. population. To estimate what the total

393 value could be under a higher level of public awareness, we also reported the value after the

394 short educational information had been received (using the same methods as above). 
Ecosystem services of the Arctic NWR

We assumed that the aesthetic value of the Refuge was incorporated into the survey

completed in the section for Total Non-use Value.

We assumed inspiration for culture and art was incorporated into values obtained from

401 place a high cultural value on the landscape of the Refuge and surrounding lands (Parlee and

402 Berkes 2005). Since the culture of these populations is so dependent on the local environment

403 and would radically change without the resources of the Refuge, it is also difficult to monetize

404 this value.

\section{Spiritual Experience}

We assumed spiritual values were included in the survey for Total Non-use Value. As having extraordinary spiritual value, but we find this value incalculable.

\section{Cognitive Development}

To develop a value for cognitive development, we utilized the annual park budget as well

411 as funds spent on research within the Refuge. To calculate the value spent to protect the gene

412 pool in Arctic National Wildlife Refuge, we used the total value of the 2016 fiscal year budget

413 for the Refuge, which was provided by a refuge staff member (J. Reed, personal

414 communication). We then divided the total budget value by the number of hectares in the refuge

415 to identify the value per hectare. For research information, we contacted the Refuge and

416 requested information on all research projects being performed in the Refuge. We identified ten

417 research projects taking place in the Refuge and contacted each researcher attached to each of these projects. We received responses from eight out of the ten researchers and recorded their 
Ecosystem services of the Arctic NWR

419

420

421

422

423

424

425

426

427

428

429

430

431

432

433

434

435

436

437

438

439

440

441

responses for their total budget. To develop an annual budget, we divided the total budget by the number of the years they will be working and added all of the annual budgets together. With this sum of the money spent annually on research in the Refuge, we divided by the total number of hectares in the Refuge to calculate the value per hectare per year.

Recreation

We assumed recreation was both a consumptive (e.g., hunting) and a non-consumptive (e.g., hiking) direct use value (Pascual et al. 2010). We utilized recreation expenditures as a proxy for recreational value. To calculate this value for recreation each year, we first identified the number of visitors to the park in the year 2016 by directly contacting refuge staff. We utilized a public use report released by the U.S. Fish and Wildlife Service that gave us the percentages of visitors who came for hunting and those who came for non-hunting recreational activities (USFWS 2010). We surveyed 11 different outfitters and determined the average cost of 29 different recreational trips offered. We repeated this method for every hunting guide who had legal access into the Refuge. We surveyed guide services with public prices and averaged the price of 21 guided hunts and 17 trophy fees. Based off the public use survey, every hunter takes a trophy with their hunt. We then multiplied the number of visitors by the percentage of recreation usage and the proportion who came for hunting. We then multiplied the individual population numbers times the average cost of the respective trips. After summing these numbers, we then divided the total money spent on the ground by the number of hectares in that park to get our specific value per hectare. In addition, we used a visitor study (Christensen et al. 2017) to determine the home location of visitors and then found the average cost of a flight from the major airport in the area of their home state to the Fairbanks airport. To calculate the average cost of an international flight, we determined the average cost of a flight to Alaska from the 
Ecosystem services of the Arctic NWR

442 seven largest airports outside the U.S. Flights from major cities in Alaska to recreational

443 locations are included in guide packages (described above). All of these average travel costs

444 were then added together and divided by the number of hectares in the Refuge to calculate the

445 average travel cost per hectare.

Detailed examination of 1002 Area

Since there is controversy over oil drilling in the 1002 Area, we performed an analysis of

448 this specific region for select variables that differ geographically within the Refuge and for

449 which we had detailed spatial data that allowed us to analyze this variation. Both carbon and

450 nitrogen values have GIS layers readily available with enough resolution to discern variation

451 within the Refuge, so we calculated the ES values for Climate Regulation and amounts of

452 nitrogen for Soil Fertility using the same methods described above. Since we originally used

453 broad estimates for phosphorus $(\mathrm{P})$ and potassium $(\mathrm{K})$ and there are no spatial data available, we

454 did not adjust them for the 1002 Area, so only the variation in nitrogen values affected the soil

455 fertility calculations. The climate regulation values were added to the broad estimates for the

456 other ES categories to calculate a total for the 1002 Area while the soil fertility amounts are

457 provided for informational purposes.

459 Results

Overview

Our estimates place an annual value of about 13 billion USD for the Arctic National

462 Wildlife Refuge, for a per hectare value of 1,708.94 USD (Table 1). The majority of these ES

463 values originate from two categories: climate regulation and non-use values, which together

464 account for $99 \%$ of ecosystem services. These two are explained in detail below. In addition, we 
Ecosystem services of the Arctic NWR

465 have also included a detailed description of the amounts for soil fertility maintenance in the

466 Refuge because these stored amounts contribute to other important ecosystem services (e.g.,

467 provisioning and aesthetic information).

\section{Climate regulation}

Over $90 \%$ of the ES value for carbon in the Arctic National Wildlife Refuge can be

470 attributed to carbon stored in the permafrost of the soil, mostly as carbon dioxide $\left(\mathrm{CO}_{2}\right)$ with

471 smaller amounts of methane $\left(\mathrm{CH}_{4}\right.$, Table 2$)$. Methane is a relatively small proportion of the

472 stored carbon (about 2\%), but because of the increased global climate change impacts of

473 methane (about 21 times greater than $\mathrm{CO}_{2}$ ), it makes up about one-third of the stored carbon ES

474 value. As a low productivity environment in a higher latitude, smaller amounts of carbon are

475 stored as live biomass (Table 2). This region continues to act as a carbon sink, although the

476 annual amount of carbon per hectare stored is small. There is also much variation in soil

477 sequestration, with some areas absorbing larger amount of carbon each year and other areas

478 acting as carbon sources (Fig. 3).

$479 \quad$ Non-use Valuation

Willingness to pay values were utilized to estimate non-use cultural values (aesthetic,

481 spiritual, inspiration for art and culture) and preference for protection from a survey of U.S.

482 citizens (Table 3). Surprisingly, only 47\% of the survey participants were aware of the Arctic

483 National Wildlife Refuge, and so a relatively small proportion of people were able to give a

484 contingent valuation. However, a large majority who were aware of the Refuge did not support

485 oil exploration and drilling and were willing to forego a considerable amount of income, which

486 produced a large monetary value. When given a short, neutral, educational statement about the

487 Refuge, a slightly smaller, but still considerable majority of the survey participants (which now 
Ecosystem services of the Arctic NWR

488 included all) supported maintaining the Refuge in its natural state. Using this value would

489 increase the contingent valuation by more than $78 \%$ and increase total ES values for the Arctic

490 National Wildlife Refuge by about one-third. However, we retained the conservative value

491 (before educational information) for our comprehensive ES estimate (Table 1) since we believe it

492 more accurately represents the current state of the contingent valuation for U.S. population.

493 Soil Fertility Maintenance

494 The three major limiting nutrients of the soil estimated (N, K, P) are abundant in this

495 system (Table 2). It should be noted that these nutrients help promote ecosystem function in the

496 region, although provisioning services are relatively small due to the small human population

497 benefitting from these services. Due to the remoteness and harsh environment, the nutrients are

498 not readily accessible to human activity or benefit, but the Refuge may create economic benefits

499 by preventing their release into the environment.

$500 \quad 1002$ Area

501

Since we had no way to determine the variation in most ES across the Refuge, we assumed values other than carbon were a constant value per hectare regardless of location. When 503 considering the variation in carbon, comprehensive ES values for the 1002 Area were estimated

504 at 1705.79 USD. This value is slightly lower compared to the corresponding value for the Refuge

505 as a whole. While the amount of carbon stored in the soil and amount sequestered was higher in 506 this region, the amount of live biomass was considerably lower (Table 2).

507

508

\section{Discussion}

The overall estimated value of 1,708.94 USD/ha/year is lower than most other terrestrial biomes (Costanza et al. 2014), although higher than the desert biome (Taylor et al. 2017). Two 
Ecosystem services of the Arctic NWR

511 ES categories (climate regulation and total non-use value) made up over $99 \%$ of the total value.

512 This result is not entirely surprising since Arctic tundra lacks some of the resources that tend to

513 increase other terrestrial biomes values, such as food production and raw materials (e.g., wood).

514 Additionally, human population density in the region is extremely small, so that local ES values

515 are relatively small, albeit not for the local individuals relying upon these ES. However, the

516 Arctic tundra provides important global values, in particular the two highest values: total non-use

517 value and climate.

While the local ES estimates are relatively small in direct monetary value, it is important

to emphasize that the process of ES valuation is noted for its difficulties in accurately estimating

cultural values (Chan et al. 2012). Some groups of Native Alaskans have been strongly opposed

to oil and gas drilling in the region (e.g., Gwich'in, Krech 2005). Many of their concerns focus

522 on the negative impacts of development in a landscape that is viewed as sacred. The

523 unquantifiable aspects the Refuge maintains for cultural and spiritual well-being should,

524 therefore, not be disregarded.

Kotchen and Burger (2007) estimated the mean economic benefit of 1,141 (2005 USD)

526 per person of voting age over the 30-year period of expected oil production (about 38 USD per

527 person per year). This economic impact of oil development corresponds to a 1,378.62 (2016

528 USD) per hectare per year for the refuge. Our willingness-to-pay results from our survey

529 indicated that, based on current awareness of the Arctic National Wildlife Refuge issues, the U.S.

530 population is willing to pay less $(68 \%)$ in lost income than the value of the oil (Table 3 ).

531 However, this value is based on over one-half of the population having no knowledge of the

532 refuge, a surprisingly high number considering the amount of media attention the region has

533 garnered over the last two decades (Bengston et al. 2010). When the survey cohort was provided 
Ecosystem services of the Arctic NWR

534

535

536

537

538

539

540

541

542

543

544

545

546

547

548

549

550

551

552

553

554

555

556

with neutral educational information and we were then able to include all participants in the value estimation, the total willingness-to-pay value rose to 1,687.19 (2016 USD) per hectare per

year, which is $22 \%$ higher than the estimated oil value. Therefore, we argue that the U.S. public is currently undereducated about the Arctic National Wildlife Refuge and that increased information about the oil drilling controversy is likely to change the number of people concerned about fossil fuel development versus continued protection. While people who already have a firmly held position on drilling in the Refuge are unlikely to change their view because of new information (Teel et al. 2006), our results suggests that since a large portion of the population has no knowledge of the controversy, an education program could be impactful. Therefore, a public education program aimed at increasing the wilderness and conservation perceptions of the Refuge could change political pressure to restrict future energy development.

Our results indicate that the ES value of the 1002 Area is not higher compared the Refuge as a whole. The coastal plain region of the Refuge is probably more valuable for certain wildlife (e.g., waterfowl, caribou, polar bear), but these provide relatively small amounts of ecosystem services compared to other categories. The one caveat is that, in our survey, we did not distinguish the non-use value of the coastal plain, which, considering the charismatic wildlife dependent in that region, might be higher among U.S. residents.

The climate regulation value is important for this region, and Arctic tundra in general, because of the large amount of carbon stored as $\mathrm{CO}_{2}$ and $\mathrm{CH}_{4}$ in the permafrost. Arctic tundra has one of the largest amounts of soil sequestered carbon of any biome on Earth. However, the warming climate is putting this ES at risk. As tundra warms, permafrost is melting over large areas of the Arctic, releasing these greenhouse gases in increasing amounts (Schuur et al. 2009). Models predict that the tundra will be a net emitter of carbon by the mid- $21^{\text {st }}$ Century, although 
Ecosystem services of the Arctic NWR

557 the exact date is uncertain (Koven et al. 2011; Schaefer et al. 2011). Regardless of whether

558 energy is extracted from this region, the carbon sequestration value will be negative for the entire

559 Refuge, although the stored carbon will take many decades to be released into the atmosphere.

560 Therefore, it is important to note that the current value of climate regulation this environment

561 possesses is likely dependent on the broader human culture to solve the current greenhouse gas

562 emissions crisis.

Since the passage of U.S. Bill H.R.1 2018, the Arctic National Wildlife Refuge has been

564 undergoing an Environmental Impact Statement process regarding the potential effect of oil

565 drilling on the 1002 Area of the Refuge (BLM 2018, USDI and BLM 2019). Leases will

566 presumably be offered in the near future, although legal actions are expected to delay drilling for

567 some time (Grandoni and Eilperin 2020). If drilling does indeed proceed, impacts on the

568 environment are likely to be pervasive. Fossil fuel development has large impacts on land-use,

569 ecosystem services, landscape fragmentation, and wildlife (Jones and Pejchar 2013; Thompson

570 et al. 2015; Moran et al. 2015; 2017; Allred et al. 2015; Trainor et al. 2016). Any environmental

571 impact analysis needs to include ecosystem services loss as one the externalities associated with

572 oil drilling. The loss of non-use valuation could be particularly pronounced if the wilderness

573 characteristic of the coastal plain of the Refuge is lost. Unlike other important protected areas

574 that have tourist infrastructure and are commonly visited by the humans (e.g., Yellowstone

575 National Park), the Arctic National Wildlife Refuge is unlikely to be a major destination for

576 tourists, mostly because of costs and limited accessibility. However, our survey results indicate

577 that the public strongly values this landscape and would be willing to forego income greater (if

578 educated) than the value of any resource extraction, indicating support for oil drilling is limited

579 and that the damage could reduce its long-term ES value. This result shows the value people 
bioRxiv preprint doi: https://doi.org/10.1101/2020.03.09.983999; this version posted March 12, 2020. The copyright holder for this preprint (which was not certified by peer review) is the author/funder, who has granted bioRxiv a license to display the preprint in perpetuity. It is made available under aCC-BY-NC-ND 4.0 International license.

\section{Ecosystem services of the Arctic NWR}

580 place on remote and undeveloped parts of the world, which includes much of the greater Arctic

581 region.

582

583 
Ecosystem services of the Arctic NWR

584

585

586

587

588

589

590

591

592

593

594

595

596

597

598

599

600

601

602

603

604

\section{References}

ADEC (Alaska Department of Environmental Conservation) (2016) Alaska Water and Sewer Challenge FAQs. Alaska Department of Environmental Conservation- Division of Water. https://watersewerchallenge.alaska.gov/WSCFAQs.htm. Accessed 17 November 2016

Allred BW, Smith WK, Twidwell D, Haggerty JH, Running SW, Naugle DE, Fuhlendorf SD (2015) Ecosystem services lost to oil and gas in North America. Science 348:401-402. https//doi.org/10.1126/science.aaa4785

Attanasi ED (2005) Economics of 1998 US Geological Survey's 1002 Area regional assessment: an economic update [Arctic National Wildlife Refuge] (No. 2005-1359). U.S. Department of Interior, Washington, D.C., USA

Bengston DN, Fan DP, Kaye R (2010) The national public's values and interests related to the Arctic National Wildlife Refuge: A computer content analysis. Int J Wilderness 16:13-20.

Bhatt US, Walker DA, Raynolds MK, Bieniek PA, Epstein HE, Comiso JC, Pinzon JE, Tucker CJ, Polyakov IV (2013) Recent declines in warming and vegetation greening trends over pan-Arctic tundra. Remote Sens 5:4229-4254. https://doi.org/10.3390/rs5094229

Bird KJ, Charpentier RR, Gautier DL, Houseknecht DW, Klett TR, Pitman JK, Moore TE, Schenk CJ, Tennyson ME, Wandrey CR (2008) Circum-Arctic resource appraisal: estimates of undiscovered oil and gas north of the Arctic Circle (No. 2008-3049). Geological Survey and U.S. Department of the Interior, Reston, VA, USA

BirdLife International (2018) Data Zone. Available from: https://datazone.birdlife.org/home. Accessed 01 December 2018 
Ecosystem services of the Arctic NWR

BLM (2018) Coastal Plain Oil and Gas Leasing Program EIS. Department of the Interior, Washington D.C., USA. https://www.blm.gov/programs/planning-and-nepa/plans-indevelopment/alaska/coastal-plain-eis. Accessed 17 November 2020

Boulanger J, Poole KG, Gunn A, Wierzchowski J (2012) Estimating the zone of influence of industrial developments on wildlife: a migratory caribou Rangifer Tarandus groenlandicus and diamond mine case study. Wildlife Biol 18:164-179. https//doi.org/10.2981/11-045

Brabets TP, Wang B, Meade RH (2000) Environmental and hydrologic overview of the Yukon River Basin, Alaska and Canada. U.S. Geological Survey: Water Resource Investigations Report 99-4204. U.S Department of the Interior, Reston, VA, USA

Brown G (2002) Alaska exceptionality hypothesis: Is Alaska wilderness really different? IN: Watson AE et al. (eds) Wilderness in the circumpolar north: searching for compatibility in ecological, traditional, and ecotourism values. US Department of Agriculture, Ogden, UT, USA, pp 105-114

Brown S, Bart J, Lanctot RB, Johnson JA, Kendall S, Payer D, Johnson J (2007) Shorebird abundance and distribution on the coastal plain of the Arctic National Wildlife Refuge. Condor 109:1-14. https//doi.org/10.1093/condor/109.1.1

Brunekreef B, Holgate ST (2002) Air pollution and health. The Lancet 360:1233-1242. https//doi.org/10.1016/S0140-6736(02)11274-8

CAFF (Conservation of Arctic Flora and Fauna, Working Group) (2015) The Economics of Ecosystems and Biodiversity (TEEB) Scoping Study for the Arctic. Conservation of Arctic Flora and Fauna, Akureyri, Iceland 
Ecosystem services of the Arctic NWR

627 Center for Indigenous People's Nutrition and Environment (2008) Inuit Health Survey 2007-

628 2008. https://www.mcgill.ca/cine/resources/ihs. Accessed 18 January 2016

629 Chan KM, Satterfield T, Goldstein J (2012) Rethinking ecosystem services to better address and navigate cultural values. Ecol Econ 74:8-18. https//doi.org/10.1016/j.ecolecon.2011.11.011

637 Christiansen JS, Mecklenburg CW, Karamushko OV (2014) Arctic marine fishes and their fisheries in light of global change. Global Chang Biol 20:352-359. O'neill RV, Paruelo J, Raskin RG (1997) The value of the world's ecosystem services and natural capital. Nature 387:253-260. https//doi.org/10.1038/387253a0

643 Costanza R, Folke C (1997) Valuing ecosystem services with efficiency, fairness and 
Ecosystem services of the Arctic NWR

646

647

648

649

650

651

652

653

654

655

656

657

658

659

660

661

662

663

664

665

Costanza R, de Groot R, Sutton P, Van der Ploeg S, Anderson SJ, Kubiszewski I, Farber S, Turner RK (2014) Changes in the global value of ecosystem services. Global Environ Chang 26:152-158. https//doi.org/10.1016/j.gloenvcha.2014.04.002

Costanza R, de Groot R, Braat L, Kubiszewski I, Fioramonti L, Sutton P, Farber S, Grasso M (2017) Twenty years of ecosystem services: how far have we come and how far do we still need to go? Ecosyst Serv 28:1-16. https://doi.org/10.1016/j.ecoser.2017.09.008

de Groot RS, Wilson MA, Boumans RM (2002) A typology for the classification, description and valuation of ecosystem functions, goods and services. Ecol Econ 41: 93-408. https//doi.org/10.1016/S0921-8009(02)00089-7

de Groot RS, Brander L, Van Der Ploeg S, Costanza R, Bernard F, Braat L, Christie M, Crossman N, Ghermandi A, Hein L, Hussain S (2012) Global estimates of the value of ecosystems and their services in monetary units. Ecosyst Serv 1:50-61. https//doi.org/10.1016/j.ecoser.2012.07.005

Dentener FJ (2006) Global Maps of Atmospheric Nitrogen Deposition, 1860, 1993, and 2050. ORNL DAAC, Oak Ridge, Tennessee, USA. https://dx.doi.org/10.3334/ORNLDAAC/830

Douglas DC, Reynolds PE, Rhod EB (2002) Arctic Refuge coastal plain terrestrial wildlife research summaries. U.S. Geological Survey, Biological Resources Division, Biological Science Report USGS/BRD/BSR-2002-0001. U.S Department of the Interior.

Reston, VA, USA 
Ecosystem services of the Arctic NWR

666

667

668

669

670

671

672

673

674

675

676

677

678

679

680

681

682

683

684

685

Estes JA, Palmisano JF (1974) Sea otters: their role in structuring nearshore communities.

Science 185:1058-1060. https//doi.org/10.1126/science.185.4156.1058

FEMA (2016) FEMA Flood Map Service Center. U.S. Department of Homeland Security. Available at https://msc.fema.gov/portal/home. Accessed 17 October 2015

Genet H, Kurkowski T, Zhu Z (2017) Alaska Land Carbon Assessment Data: U.S. Geological Survey data release. https//doi.org/10.5066/F7TD9W8Z

Grandoni DJ, Eilperin (2020) The Energy 202: Trump administration delays Arctic refuge oil leasing to strengthen legal case. Washington Post. Washington DC, USA.

Hansen J, Sato M, Ruedy R, Lo K, Lea EW, Medina-Elizade M (2006) Global temperature change. Proc Natl Acad Sci USA 103:14288-14293. https//doi.org/10.1073/pnas.0606291103

Hansen J, Ruedy R, Sato M, Lo K (2010) Global surface temperature change. Rev Geophys 48:RG4004. https//doi.org/10.1029/2010RG000345

Harsem Ø, Eide A, Heen K (2011) Factors influencing future oil and gas prospects in the Arctic. Energ Policy 39:8037-8045. https//doi.org/10.1016/j.enpol.2011.09.058

Hovelsrud GK, Poppel B, Van Oort B, Reis JD (2011) Arctic societies, cultures, and peoples in a changing cryosphere. Ambio 40:100-110. https//doi.org/10.1007/s13280-011-0219-4

H.R.1 -1 (2018) H.R.1 - An Act to provide for reconciliation pursuant to titles II and V of the concurrent resolution on the budget for fiscal year 2018. https://www.congress.gov/bill/115th-congress/house-bill/1/text 
Ecosystem services of the Arctic NWR

701

702

703

704

Hunter-Cevera JC (1998) The value of microbial diversity. Curr Opin Microbiol 1:278-285. https//doi.org/10.1016/S1369-5274(98)80030-1

Ibisch PL, Hoffmann MT, Kreft S, Pe'er G, Kati V, Biber-Freudenberger L, DellaSala DA, Vale MM, Hobson PR, Selva N (2016) A global map of roadless areas and their conservation status. Science 354:1423-1427. https//doi.org 10.1126/science.aaf7166

IPCC (2007) Climate Change 2007: Synthesis Report. Contribution of Working Groups I, II and III to the Fourth Assessment Report of the Intergovernmental Panel on Climate Change Core Writing Team, Pachauri RK, Reisinger A (eds). IPCC, Geneva, Switzerland

Johnson CJ, Boyce MS, Case RL, Cluff HD, Gau RJ, Gunn A, Mulders R (2005) Cumulative effects of human developments on arctic wildlife. Wildlife Monogr 160:1-36. https//doi.org/10.2193/0084-0173(2005)160[1:CEOHDO]2.0.CO;2

Johnson CJ, Russell DE (2014) Long-term distribution responses of a migratory caribou herd to human disturbance. Biol Conserv 177:52-63. https//doi.org/10.1016/j.biocon.2014.06.007

Jones NF, Pejchar L (2013) Comparing the ecological impacts of wind and oil \& gas development: a landscape scale assessment. PLoS One 8:e81391. https//doi.org/10.1371/journal.pone.0081391

Konrad CP (2003) Effects of urban development on floods. Fact Sheet, No. 076-03. U.S. Geological Survey, Reston, VA, USA

Kotchen MJ, Burger NE (2007) Should we drill in the Arctic National Wildlife Refuge? An economic perspective. Energ Policy 35:4720-4729. https//doi.org/10.1016/j.enpol.2007.04.007 
Ecosystem services of the Arctic NWR

Koven CD, Ringeval B, Friedlingstein P, Ciais P, Cadule P, Khvorostyanov D, Krinner G, Tarnocai C (2011) Permafrost carbon-climate feedbacks accelerate global warming. Proc Natl Acad Sci USA 108:14769-14774. https//doi.org/10.1073/pnas.1103910108

Krech S (2005) Reflections on conservation, sustainability, and environmentalism in indigenous North America. Am Anthropol 107:78-86. https//doi.org/10.1525/aa.2005.107.1.078

Law KS, Stohl A (2007) Arctic air pollution: Origins and impacts. Science 315:1537-1540. https//doi.org/10.1126/science.1137695

Livingston JM, Smith DG, Froese DG, Hugenholtz CH (2009) Floodplain stratigraphy of the ice jam dominated middle Yukon River: a new approach to long-term flood frequency. Hydrol Process 23:357-371. https//doi.org/10.1002/hyp.7106

Luick B (2017) Alaska Food Cost Survey. University of Alaska Fairbanks Cooperative Extension Service. https://www.uaf.edu/ces/hhfd/fcs/. Accessed 11 September 2017

Malinauskaite L, Cook D, Davíðsdóttir B, Ögmundardóttir H, Roman J (2019) Ecosystem services in the Arctic: a thematic review. Ecosyst Serv 36:100898. https//doi.org/10.1016/j.ecoser.2019.100898

Moran MD, Cox AB, Wells RL, Benichou CC, McClung MR (2015) Habitat loss and modification due to gas development in the Fayetteville Shale. Environ Manage 55:12761284. https//doi.org/10.1007/s00267-014-0440-6

Moran MD, Taylor NT, Mullins TF, Sardar SS, McClung MR (2017) Land-use and ecosystem services costs of unconventional US oil and gas development. Front Ecol Environ 15:237-242. https//doi.org/10.1002/fee.1492 
Ecosystem services of the Arctic NWR

National Research Council (2003) Cumulative environmental effects of oil and gas activities on Alaska's North Slope. National Academies Press, Washington, DC, USA

Nowak DJ, Hirabayashi S, Bodine A, Greenfield E (2014) Tree and forest effects on air quality and human health in the United States. Environ Poll 193:119-129. https//doi.org/10.1016/j.envpol.2014.05.028

Nunes PA, van den Bergh JC (2001) Economic valuation of biodiversity: sense or nonsense? Ecol Econ 39:203-222. https//doi.org/10.1016/S0921-8009(01)00233-6

O’Garra T (2017) Economic value of ecosystem services, minerals and oil in a melting Arctic: A preliminary assessment. Ecosyst Serv 24:180-186. https//doi.org/10.1016/j.ecoser.2017.02.024

Parlee B, Berkes F (2005) Health of the land, health of the people: a case study on Gwich'in berry harvesting in northern Canada. EcoHealth 2:127-137. https://doi.org/10.1007/s10393-005-3870-z

Pascual U, Muradian R, Brander L, Gómez-Baggethun E, Martín-López B, Verma M, Armsworth P, Christie M, Cornelissen H, Eppink F, Farley J (2010) The economics of valuing ecosystem services and biodiversity. In: Kumar P (ed), The economics of ecosystems and biodiversity: Ecological and economic foundations. UNEP/Earthprint, London, UK, pp. 183-256

Public Law 97-394 (1980) Alaska National Interest Lands Conservation Act of 1980. http://dnr.alaska.gov/commis/opmp/anilca/pdf/PublicLaw-96-487.pdf. Accessed 5 October 2017 
Ecosystem services of the Arctic NWR

Raftovich RV, Chandler SC, Fleming KK (2017) Migratory bird hunting activity and harvest during the 2015-16 and 2016-17 hunting seasons. U.S. Fish and Wildlife Service, Laurel, Maryland, USA

Sanderson EW, Jaiteh M, Levy MA, Redford KH, Wannebo AV, Woolmer G (2002) The human footprint and the last of the wild: the human footprint is a global map of human influence on the land surface, which suggests that human beings are stewards of nature, whether we like it or not. AIBS Bulletin 52:891-904. https//doi.org/10.1641/00063568(2002)052[0891:THFATL]2.0.CO;2

Sardans J, Peñuelas J (2015) Potassium: a neglected nutrient in global change. Global Ecol Biogeogr 24:261-275. https//doi.org/10.1111/geb.12259

Schaefer K, Zhang T, Bruhwiler L, Barrett AP (2011) Amount and timing of permafrost carbon release in response to climate warming. Tellus B 63:168-180. https//doi.org/10.1111/j.1600-0889.2011.00527.x

Schuster RC, Wein EE, Dickson C, Chan HM (2011) Importance of traditional foods for the food security of two First Nations communities in the Yukon, Canada. Int J Circumpol Heal 70:286-300. https//doi.org/10.3402/ijch.v70i3.17833

Schuur EA, Vogel JG, Crummer KG, Lee H, Sickman JO, Osterkamp TE (2009) The effect of permafrost thaw on old carbon release and net carbon exchange from tundra. Nature 459:556-559. https//doi.org/10.1038/nature08031

Schuur EA, McGuire AD, Schädel C, Grosse G, Harden JW, Hayes DJ, Hugelius G, Koven CD, Kuhry P, Lawrence DM, Natali SM (2015) Climate change and the permafrost carbon feedback. Nature 520:171-179. https//doi.org/10.1038/nature14338 
Ecosystem services of the Arctic NWR

771 Shangguan W, Dai Y, Duan Q, Liu B, Yuan H (2014) A global soil data set for earth system

772

773

774

775

776

777

778

779

780

781

782

783

784

785

786

787

788

modeling. Journal of Advances in Modeling Earth Systems 6:249-263.

https//doi.org/10.1002/2013MS000293

Shaver GR, Billings WD, Chapin FH, Giblin AE, Nadelhoffer KJ, Oechel WC, Rastetter EB (1992) Global change and the carbon balance of arctic ecosystems: Carbon/nutrient interactions should act as major constraints on changes in global terrestrial carbon cycling. Bioscience 42:433-441. https//doi.org/10.2307/1311862

Stankiewicz J (2005) City of Kaktovik local all hazard mitigation plan. The North Slope Borough Risk Management Division, Barrow, AK, USA

Tarnocai C, Canadell JG, Schuur EAG, Kuhry P, Mazhitova G, Zimov S (2009) Soil organic carbon pools in the northern circumpolar permafrost region. Global Biogeochem $\mathrm{Cy}$ 23:1-11. https//doi.org/10.1029/2008GB003327

Taylor NT, Davis KM, Abad H, McClung MR, Moran MD (2017) Ecosystem services of the Big Bend region of the Chihuahuan Desert. Ecosyst Serv 27:48-57. https://doi.org/10.1016/j.ecoser.2017.07.017

TEEB (2010) Mainstreaming the Economics of Nature: A Synthesis of the Approach, Conclusions and Recommendations of TEEB. Earthscan, London, UK and Washington, DC, USA

Teel TL, Bright AD, Manfredo MJ, Brooks JJ (2006) Evidence of biased processing of natural resource-related information: a study of attitudes toward drilling for oil in the Arctic 
Ecosystem services of the Arctic NWR

National Wildlife Refuge. Soc Natur Resour 19:447-463. https//doi.org/10.1 O8O/O894 1920600561140

Thompson SJ, Johnson DH, Niemuth ND, Ribic CA (2015) Avoidance of unconventional oil wells and roads exacerbates habitat loss for grassland birds in the North American Great Plains. Biol Conserv 192:82-90. https//doi.org/10.1016/j.biocon.2015.08.040

Tiberi P (2017) Alaska Employment Report Joint Economic Committee. https://www.jec.senate.gov/public/_cache/files/08094e1d-c966-4a0b-b7585a44ef643261/alaska-employment-update.pdf. Accessed 17 November 2018

Tol RSJ (2008) The Social Cost of Carbon: Trends, Outliers and Catastrophes. Economics-Kiel 2:2008-25. https//doi.org/10.5018/economics-ejournal.ja.2008-25

Trainor AM, McDonald RI, Fargione J (2016) Energy sprawl is the largest driver of land use change in United States. PloS One 11:e0162269. https//doi.org/10.1371/journal.pone.0162269

United States Bureau of Land Management (1986) Arctic National Wildlife Refuge, Alaska, Coastal Plain Resource Assessment: Report and Recommendation to the Congress of the United States and Legislative Environmental Impact Statement: Draft. U.S. Department of the Interior, Washington, D.C., USA

U.S. Census Bureau (2010) United States Census Bureau Data. https://factfinder.census.gov/faces/nav/jsf/pages/community_facts.xhtml\#. Accessed 7 November 2017 
Ecosystem services of the Arctic NWR

811 U.S. Department of Agriculture, Agricultural Research Service (2016) Energy Intakes:

812

813

814

815

816

817

818

819

820

821

822

823

824

825

826

827

828

829

830

Percentages of Energy from Protein, Carbohydrate, Fat, and Alcohol, by Gender and

Age, What We Eat in America, NHANES 2013-2014. U.S. Department of Agriculture, Washington, D.C., USA

USDU (U.S. Department of the Interior) and BLM (Bureau of Land Management) (2019) Coastal Plain Oil and Gas Leasing Program. U.S. Department of the Interior and The Bureau of Land Management, Washington D.C., USA

USFWS (U.S. Fish and Wildlife Service) (2010) Public Use Summary: Arctic National Wildlife Refuge. U.S. Department of the Interior, Washington D.C., USA

USFWS (U.S. Fish and Wildlife Service) (2011) Vascular Plants of Arctic Refuge. U.S. Department of the Interior, Washington D.C., USA

USFWS (U.S. Fish and Wildlife Service) (2017a) Wildlife and Habitat: Mammal List-2017, Bird List-2010, Fish List-2010, Butterfly List-2013. U.S. Department of the Interior, Washington D.C., USA

USFWS (U.S. Fish and Wildlife Service) (2017b) Arctic Refuge Bryophyte List. U.S. Department of the Interior, Washington D.C., USA

Watson JE, Jones KR, Fuller RA, Marco MD, Segan DB, Butchart SH, Allan JRL, McDonaldMadden E, Venter O (2016) Persistent disparities between recent rates of habitat conversion and protection and implications for future global conservation targets. Conserv Lett 9:413-421. https//doi.org/10.1111/conl.12295 
Ecosystem services of the Arctic NWR

831 Whitten KR, Garner GW, Mauer FJ, Harris RB (1992) Productivity and early calf survival in the Porcupine caribou herd. J Wildlife Manage 56:201-212. https//doi.org/10.2307/3808814

833 Wookey PA, Aerts R, Bardgett RD, Baptist F, Bråthen KA, Cornelissen JH, Gough L, Hartley IP, Hopkins DW, Lavorel S, Shaver GR (2009) Ecosystem feedbacks and cascade processes: understanding their role in the responses of Arctic and alpine ecosystems to environmental change. Global Chang Biol 15:1153-1172. https//doi.org/10.1111/j.1365-

Xu X, Thornton PE, Post WM (2013) A global analysis of soil microbial biomass carbon, nitrogen and phosphorus in terrestrial ecosystems. Global Ecol Biogeogr 22:737-749. https//doi.org/10.1111/geb.12029

841 Zeller D, Booth S, Pakhomov E, Swartz W, Pauly D (2011) Arctic fisheries catches in Russia, USA, and Canada: baselines for neglected ecosystems. Polar Biol 34:955-973. https//doi.org/10.1007/s00300-010-0952-3

844 Zhang ZQ (2011) Animal biodiversity: an outline of higher-level classification and survey of taxonomic richness. Magnolia Press, Auckland, New Zealand 
Ecosystem services of the Arctic NWR

Tables

Table 1. Annual ecosystem services values estimated for the Arctic Refuge in 2016 USD. DMP = direct market price, $\mathrm{RC}=$ replacement cost, $\mathrm{AC}=$ avoidance cost, $\mathrm{CV}=$ contingent valuation .

\begin{tabular}{|c|c|c|c|}
\hline Ecosystem Service & $\begin{array}{c}\text { Value per } \\
\text { Hectare }\end{array}$ & $\begin{array}{c}\text { Valuation } \\
\text { Method }\end{array}$ & Notes \\
\hline \multicolumn{4}{|l|}{ Provisioning } \\
\hline 1. Food & 0.21 & $\mathrm{DMP} / \mathrm{RC}$ & Partially affected by 8 \\
\hline 2. Water & 0.67 & $\mathrm{DMP} / \mathrm{RC}$ & \\
\hline 3. Raw materials & 0.00 & - & Negligible \\
\hline 4. Genetic resources & 0.02 & DMP & \\
\hline 5. Medicinal resources & -- & - & Included in 4. \\
\hline 6. Ornamental resources & 0.00 & - & \\
\hline \multicolumn{4}{|l|}{ Regulating Services } \\
\hline 7. Air quality regulation & 1.26 & $\mathrm{AC}$ & \\
\hline 8. Climate regulation & 758.88 & $\mathrm{AC}$ & \\
\hline 9. Moderation of disturbance & 0.01 & $\mathrm{AC}$ & \\
\hline 10. Water flow regulation & -- & - & Included in 9 and 13 \\
\hline 11. Waste treatment & 0.02 & DMP & \\
\hline 12. Erosion prevention & -- & - & Included in 13 \\
\hline 13. Soil fertility maintenance & -- & -- & Included in 1-6 \\
\hline 14. Pollination & 0.00 & - & No crops grown \\
\hline 15. Biological control & -- & - & Included in 1 \\
\hline \multicolumn{4}{|l|}{ Habitat Services } \\
\hline 16. Nursery services & 0.10 & DMP & \\
\hline 17. Gene pool protection & -- & DMP & Included in 4 and 5 \\
\hline \multicolumn{4}{|l|}{ Cultural Services } \\
\hline 18. Total non-use value & 944.30 & $\mathrm{CV}$ & \\
\hline a. Aesthetic information & -- & $\mathrm{CV}$ & Included in 18 \\
\hline b. Inspiration (art/culture) & -- & $\mathrm{CV}$ & Included in 18 \\
\hline c. Spiritual experience & -- & $\mathrm{CV}$ & Included in 18 \\
\hline 19. Cognitive development & 0.58 & DMP & \\
\hline 20. Recreation & 2.89 & DMP & \\
\hline Total (per hectare) & $1,708.94$ & & \\
\hline Total (region) & $38,599,631$ & & \\
\hline
\end{tabular}


Ecosystem services of the Arctic NWR

855 Table 2. Total amounts and ecosystem services (ES) values of carbon and amounts of select 856 nutrients stored in the Arctic Refuge. Note that ES values for sources stored in soil and live

857 biomass are prorated over 25 years. Values given in 2016 USD.

858

\begin{tabular}{|c|c|c|c|c|c|}
\hline \multicolumn{6}{|c|}{ Entire Refuge } \\
\hline \multirow[t]{2}{*}{ Source } & \multicolumn{5}{|c|}{ Amount per Hectare } \\
\hline & $\begin{array}{c}\text { Carbon } \\
\text { (tonnes in } \mathrm{CO}_{2} \text { form) }\end{array}$ & $\begin{array}{c}\text { Carbon } \\
\text { (tonnes in } \mathrm{CH}_{4} \text { form) }\end{array}$ & $\begin{array}{l}\text { Nitrogen } \\
\text { (tonnes) }\end{array}$ & $\begin{array}{l}\text { Phosphorus } \\
\text { (tonnes) }\end{array}$ & $\begin{array}{l}\text { Potassium } \\
\text { (tonnes) }\end{array}$ \\
\hline \multirow{5}{*}{$\begin{array}{l}\text { Live biomass } \\
\text { Stored in soil } \\
\text { Annual } \\
\text { sequestration }\end{array}$} & 32.26 & - & - & - & -1 \\
\hline & 337.48 & 6.89 & 18.40 & 0.24 & 0.46 \\
\hline & 0.03 & - & 0.0003 & - & - \\
\hline & \multicolumn{5}{|c|}{ Annual Ecosystem Service Value per Hectare } \\
\hline & Carbon $\left(\mathrm{CO}_{2}\right.$ form $)$ & Carbon $\left(\mathrm{CH}_{4}\right.$ form $)$ & Nitrogen & Phosphorus & Potassium \\
\hline Live biomass & 47.53 & - & - & - & - \\
\hline Stored in soil & 497.18 & 213.08 & - & - & - \\
\hline $\begin{array}{l}\text { Annual } \\
\text { sequestration }\end{array}$ & 1.10 & - & - & - & - \\
\hline \multicolumn{6}{|c|}{1002 Area } \\
\hline \multirow[t]{2}{*}{ Source } & \multicolumn{5}{|c|}{ Amount per Hectare } \\
\hline & $\begin{array}{c}\text { Carbon } \\
\text { (tonnes in } \mathrm{CO}_{2} \text { form) }\end{array}$ & $\begin{array}{c}\text { Carbon } \\
\text { (tonnes in } \mathrm{CH}_{4} \text { form) } \\
\end{array}$ & $\begin{array}{r}\text { Nitrogen } \\
\text { (tonnes) } \\
\end{array}$ & $\begin{array}{r}\text { Phosphorus } \\
\text { (tonnes) }\end{array}$ & $\begin{array}{r}\text { Potassium } \\
\text { (tonnes) } \\
\end{array}$ \\
\hline Live biomass & 6.29 & - & - & - & - \\
\hline Stored in soil & 350.91 & 7.16 & 19.40 & 0.24 & 0.46 \\
\hline \multirow{3}{*}{$\begin{array}{l}\text { Annual } \\
\text { sequestration }\end{array}$} & 0.21 & - & 0.0027 & - & - \\
\hline & \multicolumn{5}{|c|}{ Annual Ecosystem Service Value per Hectare } \\
\hline & Carbon $\left(\mathrm{CO}_{2}\right.$ form $)$ & Carbon $\left(\mathrm{CH}_{4}\right.$ form $)$ & Nitrogen & Phosphorus & Potassium \\
\hline Live biomass & 9.26 & - & - & - & - \\
\hline Stored in soil & 516.97 & 221.56 & - & - & - \\
\hline $\begin{array}{l}\text { Annual } \\
\text { sequestration }\end{array}$ & 7.73 & - & - & - & - \\
\hline
\end{tabular}


Table 3. Results of the contingent valuation survey for the Arctic National Wildlife Refuge. Survey details described in Appendix I. N $=315$ participants.

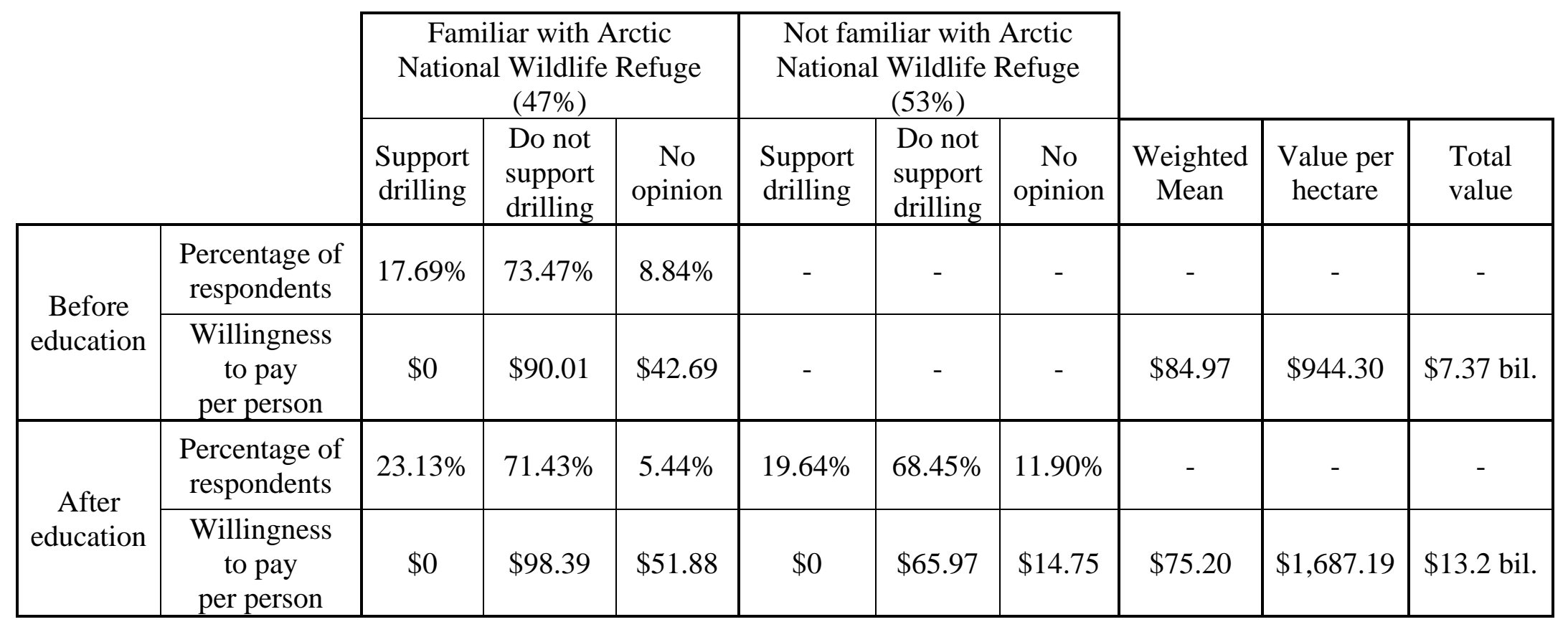


Ecosystem services of the Arctic NWR

\section{Figure legends}

Fig. 1. Map of the Arctic National Wildlife Refuge in relation to the 1002 area, Canada, and the U.S. state of Alaska (inset).

Fig. 2. Framework modeled on TEEB (2010) and used in this paper to consider ecosystem services of the Arctic National Wildlife Refuge. Some services (e.g., ornamental resources, pollination) were omitted if there were no data to allow for valuation.

Fig. 3. Spatial distribution of variables used to calculate the ecosystem services value for climate regulation in the Arctic Refuge. Variables include the amount of land carbon $\left(\mathrm{g} / \mathrm{m}^{2}\right)$ assessed over the time period from 2000-2009 that is a) stored in the soil, b) stored in live biomass, and c) sequestered annually. Data source: USGS 2017 Alaska Land Carbon Data Assessment. 

available under aCC-BY-NC-ND 4.0 International license.

Ecosystem services of the Arctic NWR

Fig. 1

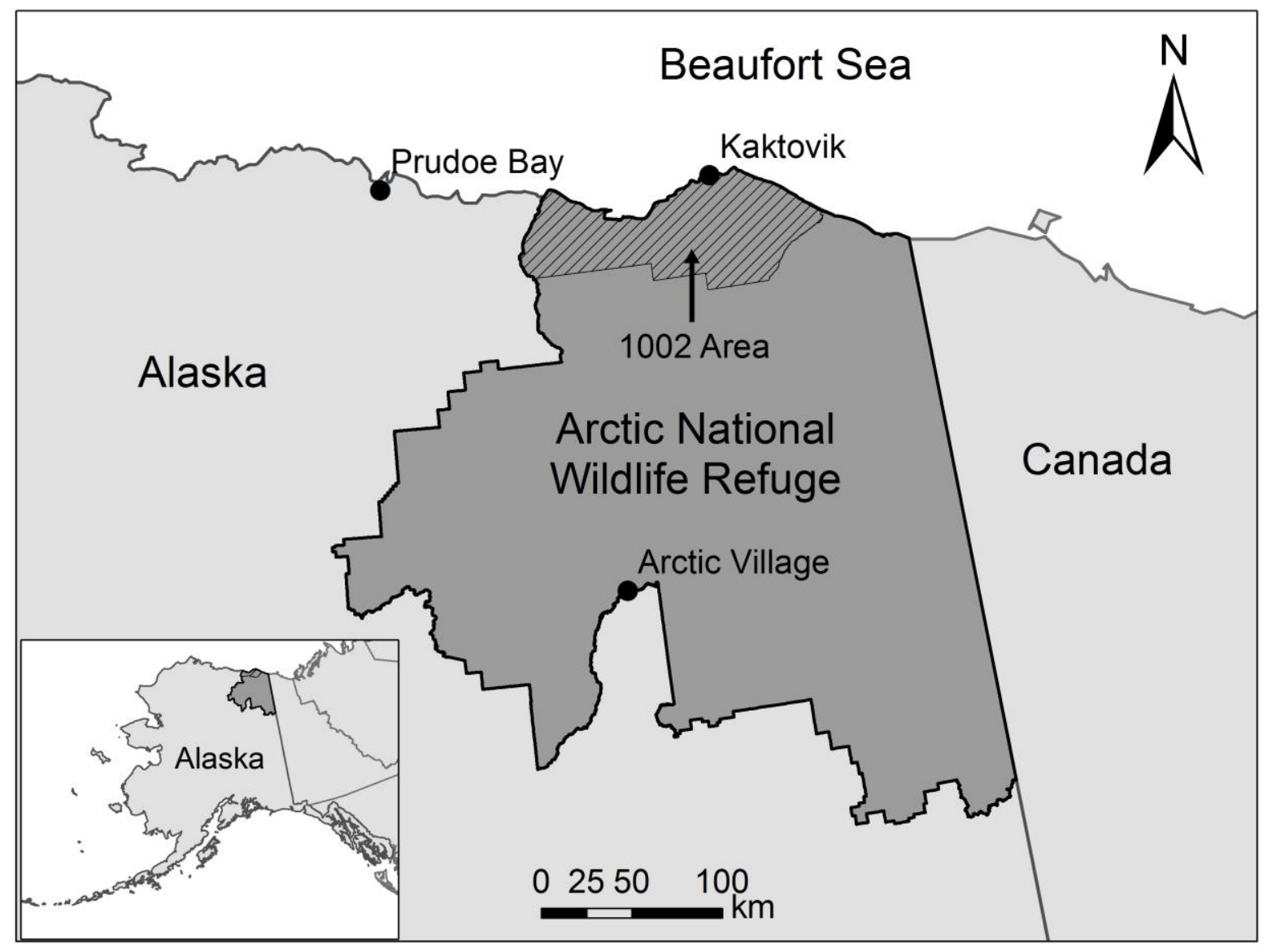


bioRxiv preprint doi: https://doi.org/10.1101/2020.03.09.983999; this version posted March 12, 2020. The copyright holder for this preprint (which was not certified by peer review) is the author/funder, who has granted bioRxiv a license to display the preprint in perpetuity. It is made available under aCC-BY-NC-ND 4.0 International license.

\section{Ecosystem services of the Arctic NWR}

Fig. 2.

\section{Total economic value}

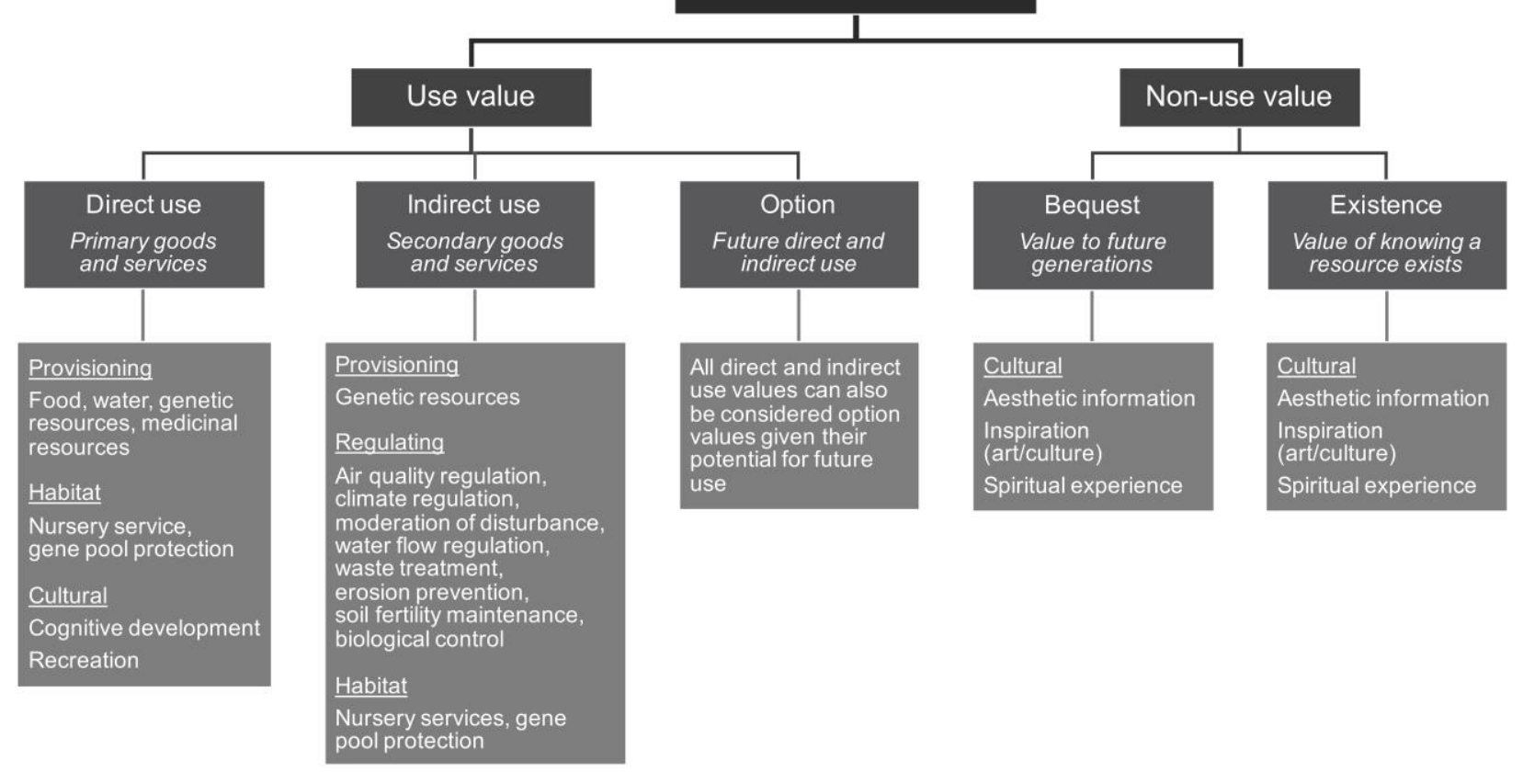


bioRxiv preprint doi: https://doi.org/10.1101/2020.03.09.983999; this version posted March 12, 2020. The copyright holder for this preprint (which was not certified by peer review) is the author/funder, who has granted bioRxiv a license to display the preprint in perpetuity. It is made available under aCC-BY-NC-ND 4.0 International license.

\section{Ecosystem services of the Arctic NWR}
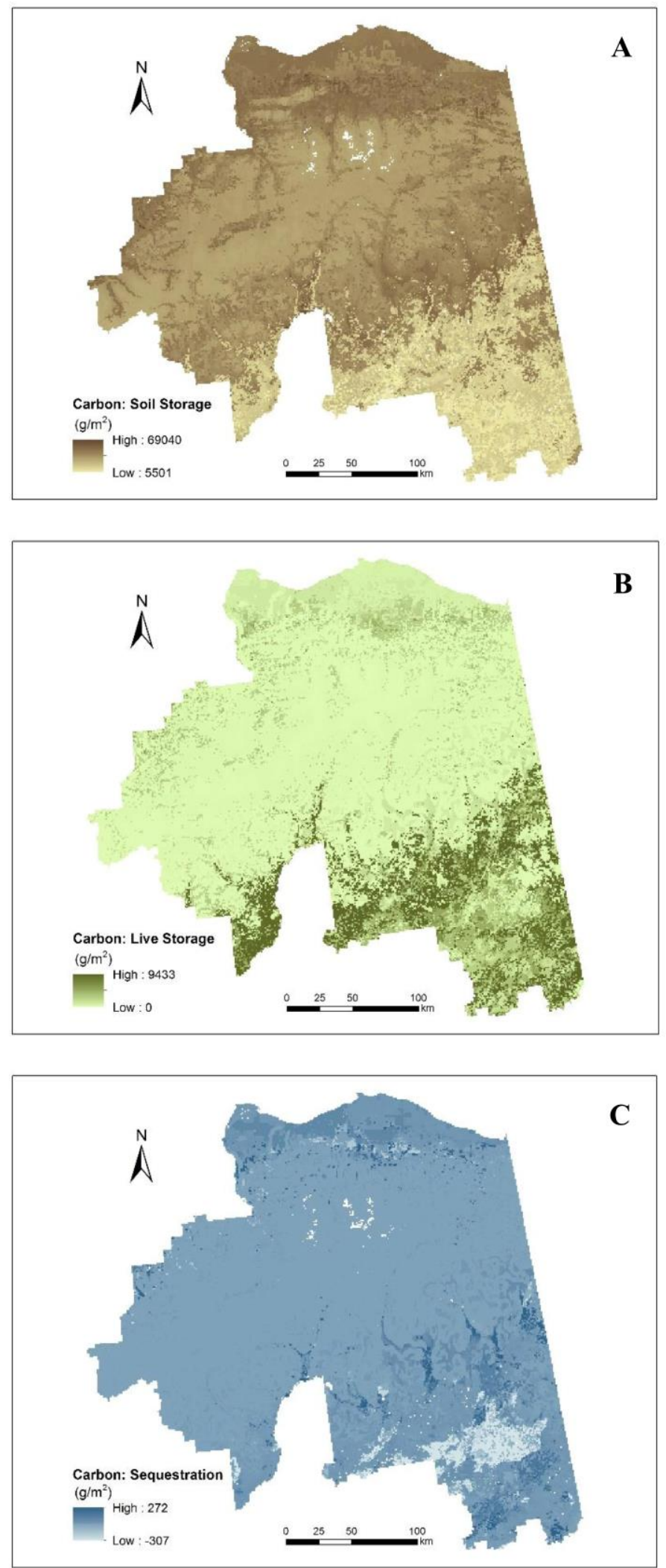

Fig. 3. 
Ecosystem services of the Arctic NWR

Appendix. Structure of the contingent valuation survey provided to a selection of U.S. residents.

Arctic National Wildlife Refuge National Survey (5 minutes)

Please only take this survey if you are 18 years or older.

1. Are you 18 years or older?
a. Yes [directed to part 2]
b. No [survey ends]

2. Are you familiar with the Arctic National Wildlife Refuge (Arctic National Wildlife Refuge)?

a. Yes [directed to part 3]

b. No [directed to part 5 Arctic National Wildlife Refuge description]

3. Do you support oil and gas drilling in the Arctic National Wildlife Refuge (Arctic National Wildlife Refuge)?
a. Yes [directed to part 4]
b. No [directed to part 4]
c. Don't Know/No Opinion [directed to part 4]

4. Considering your annual income, how much money would you be willing to give up per year in order to continue a ban on oil and gas drilling in the Arctic National Wildlife Refuge (Arctic National Wildlife Refuge)? If you select "other", please enter an amount in US Dollars (\$).
a. $\$ 50 \quad$ [directed to part 5]
b. $\$ 100$ [directed to part 5]
c. \$200 [directed to part 5]
d. $\$ 500$ [directed to part 5]
e. Other: [directed to part 5]

5. Read Description of Arctic National Wildlife Refuge

The Arctic National Wildlife Refuge is one of the largest undeveloped areas in North America. It has the most species of any similar size area in the Arctic, including one of the largest caribou herds in the world. Currently, it is fully protected from development and human activities other than recreation.

The area is also believed to contain a large oil and gas deposit. The Tax Cuts and Jobs Act passed by Congress in 2017 opened about 8\% of the Arctic National Wildlife Refuge to oil and gas drilling.

It is expected that this portion of the refuge will produce an estimated 7.7 billion barrels of oil over 30 years, which represents about $5 \%$ of the expected US total production.

Some Americans believe that the area should remain undeveloped as a nature preserve, while others believe the US should utilize the oil and gas deposits in the refuge.

6. Now that you have read the previous paragraph, do you support oil and gas drilling in the Arctic National Wildlife Refuge (Arctic National Wildlife Refuge)?
a. Yes [directed to part 7]
b. No [directed to part 7] 
Ecosystem services of the Arctic NWR

\section{c. Don't Know/No Opinion [directed to part 7]}

7. Considering your annual income, how much money would you be willing to give up in order to continue a ban on oil and gas drilling in the Arctic National Wildlife Refuge (Arctic National Wildlife Refuge)? If you select "other", please enter an amount in US Dollars (\$).
a. $\$ 50 \quad$ [survey ends]
b. $\$ 100$ [survey ends]
c. $\$ 200$ [survey ends]
d. $\$ 500$ [survey ends]
e. Other: [survey ends] 